\title{
POLYCODE: CREOLIZED TEXT AS MANIPULATION MEANS
}

\section{POLYCODE: TEXTO CREOLIZADO COMO MEIO DE MANIPULAÇÃO}

POLYCODE: TEXTO CRIOLIZADO COMO MEDIO DE MANIPULACIÓN

\author{
Viktoriya Jurevna GARAEVA ${ }^{1}$ \\ Irina Vladimirovna VASHUNINA ${ }^{2}$
}

\begin{abstract}
One way of influencing is to creolize a text. In the current study, it was discussed the manipulative potential of creolized texts. Adding an illustration to a verbal text allows the reader to visualize information and create a planned impact on the recipient other than the impact of a verbal text, i.e., the content of the verbal text is modified. Three groups of tactics were identified during the study: 1) supporting tactics (the content of the text receives support from the illustration); 2) transforming tactics (text content transformation); 3) distracting tactics (distraction of the addressee from the verbal text content). Using the tactics of the first group, one can "say" the same thing via an illustration; using the tactics of the second group; one can add ideas, change the content of the verbal text, and using the tactics of the third group, one can distract the recipients from the verbal text content.
\end{abstract}

KEYWORDS: Multicode. Creolized text. Manipulation. Transforming tactics. Supporting tactics. Distracting tactics.

RESUMO: Uma maneira de influenciar é tornar um texto creolizado. No presente estudo, procurou-se discutir o potencial de manipulação dos textos crioulos. Adicionar uma ilustração a um texto verbal pode auxiliar a visualizar informações e causar um impacto planejado no destinatário, além do impacto do texto verbal, ou seja, o conteúdo do texto verbal é modificado. Três grupos de táticas foram identificados durante o estudo: 1) táticas de apoio (o conteúdo do texto recebe suporte da ilustração); 2) táticas transformadoras (transformação do conteúdo do texto); 3) táticas de distração (causando distração do destinatário quanto ao conteúdo do texto verbal). Usando as táticas do primeiro grupo, pode-se "dizer" a mesma coisa por meio de uma ilustração; usando as táticas do segundo grupo; pode-se acrescentar algo, mudar o conteúdo do texto verbal e, usando as táticas do terceiro grupo, pode-se distrair os destinatários do conteúdo do texto verbal.

PALAVRAS-CHAVE: Multicódigo. Texto creolizado. Manipulação. Táticas transformadoras. Táticas de apoio. Táticas de distração.

1 Kazan Federal University (KPFU), Kazan - Russia. Assistant of Applied and Experimental Linguistics Department, Institute of Philology and Intercultural Communication. ORCID: https://orcid.org/0000-0002-21058776. E-mail: viktoria-dom@mail.ru

2 Peoples' Friendship University of Russia (RUDN), Moscow - Russia. Doctor of Philology, Associate Professor, Professor at the Department of Theory and Practice of Foreign Languages. ORCID: https://orcid.org/0000-00024661-8215. E-mail: vashunina@yandex.ru 
RESUMEN: Una forma de influir es criollizar un texto. En el estudio actual, se intentó discutir el potencial manipulador de los textos criollos. Agregar una ilustración a un texto verbal puede visualizar información y tener un impacto planificado en el destinatario que no sea el impacto del texto verbal, es decir, se modifica el contenido del texto verbal. Se identificaron tres grupos de tácticas durante el estudio: 1) tácticas de apoyo (el contenido del texto recibe apoyo de la ilustración); 2) tácticas de transformación (transformación del contenido del texto); 3) tácticas de distracción (distracción del destinatario del contenido del texto verbal). Utilizando las tácticas del primer grupo, se puede "decir" lo mismo mediante una ilustración; usando las tácticas del segundo grupo; se puede agregar algo, cambiar el contenido del texto verbal y, utilizando las tácticas del tercer grupo, se puede distraer a los destinatarios del contenido del texto verbal.

PALABRAS CLAVE: Multicódigo. Texto creolizado. Manipulación. Tácticas transformadoras. Tácticas de apoyo. Tácticas de distracción.

\section{Introduction}

Our time is called the information explosion period - there is an avalanche-like increase in information. We consume this information and accessing the Internet to find information has become a habit for most. Finding the things we are looking for, we do not wonder why this material was created. Usually, we consider such sources as a kind of reference, but in reality, the creators of the materials pursue specific goals. It is important to realize that any data in the media are presented with the expectation of their pragmatic impact. It is known that the primary purpose of the media is not the communication of reliable information, but the translation of specific ideas that cause particular behavior. The primary function of advertising is also not informative, but incentive - it is an incentive to purchase goods and services (FARZADNIA; GILES, 2015).

One way of influencing is to creolize a text. Adding illustrations allows you to correct the perception of a verbal text discretely for specific purposes. If we accept the definition of manipulation as a type of social influence that aims to change the behavior or perception of others through indirect, deceptive, or underhanded tactics, then it could be considered as manipulative. How the addition of an additional component takes place? The main question, to which there is no clear answer yet: what are the grounds of a manipulative effect occurrence on the mass recipient? 


\section{Theoretical framework}

Vashunina, Ryabova and Egorova (2018) state that: Hypertext is regarded as a means of communication uniting multilingual streams of conceptual sense, which is represented by means of verbal and non-verbal codes as well as perceptive images of multi-level modalities. Resistance to hidden manipulative influence is an acute problem nowadays. Hypertext as an asymmetric and polymodal phenomenon is seen from the point of view of its functioning in a communicative reality. The psycholinguistic experimental study using the method of semantic differential shows the main trends of creolized hypertext development and perception. It was identified pragmatic potential of different parameters of visual components for manipulation of the public conscience. Polycode text usage changes categorical realia of communication through information perception management which results in modification of recipients' value orientation.

The metaphoric term "creolized texts" was coined by psycholinguists U. Sorokin and E. Tarasov, who claimed that such texts consisted of two non-homogeneous entities, i.e. verbal (referring to the speech) and nonverbal (referring to other codes). According to the latest findings in creolized texts research, such texts are characterized by the presence of an iconic element which is integrated into the verbal message in reference to the aspects of semantics, compositional semantics and linguistic semantics. also creolized texts are characterized by iconic means dominant in the field of paralinguistic means. The term creolized text is not the only one used by the researchers who try to examine the notion of texts of such type. There have been suggested the following terms - semiotically complex texts, untraditional texts, video verbal texts, composed texts, polycoded texts, lingual visual phenomenon, syncretic message, isoverbal complex, isoverb, iconotext (see Anisimova, Berezin, Bernatzkaya, Bolshiyanova, Valgina, Golovina, Eyger, Zenkova, Kamenskaya, Klyukanova, Lazareva, Meskhishvili, Mikheyev, Poymanova, Sonin, Sorokin, Tarasov, Yakobson). This chain of terms outlines the opportunity for verbal and nonverbal text components interaction. According to Merzlyakov and Ignatova (2019): the conducted new research showed that an image role in the creolized text can act as predictors to understanding of verbal information that confirms the theoretical bases according to which images participate in emphasis of attention on verbal objects in the text. The most suitable images are realistic for a more adequate semantic understanding, which allows attraction when determining the meaning of the text to the internal estimation phenomenology of the reader, causing big criticality to the estimation of information. When graphics generate new meanings, it can contradict the main contents of the text - promoting 
change of an image and sense of a verbal part of the creolized text. The text deprived of images leads to more adequate understanding of author's position due to attraction to understanding not of intertextuality, but to the direct text. According to Vashunina, Ryabova and Egorova (2018, p. 29) studies, Hypertext is regarded as a means of communication unifying multilingual streams of conceptual sense, which is represented by means of verbal and non-verbal codes as well as perceptive images of multi-level modalities. Resistance to hidden manipulative influence is an acute problem nowadays. Hypertext as an asymmetric and polymodal phenomenon is seen from the point of view of its functioning in a communicative reality.

Multilanguage discourse is an ultimately important phenomenon of intercultural communications in modern society. Mankind relates the future to expanding and deepening the sphere of communications. The formation of information "hypersystems" leads to crucial changes in categorical realia of communication and its global intensification. Its unique speed and scale are represented by information technologies affecting society in general and every person in particular. Through new ways of an individual involvement, the information flows and linguistic and cultural dynamics come into existence (MOUSAVI; FARAHANI; ARIZAVI, 2014).

\section{Methodology}

Hypertext as a complicated extra-linguistic paradigm can be interpreted as a way of communication in modern society, oriented in multiple, simultaneous multilingual streams of conceptual sense. It is explicitly represented not only by the units of verbal and nonverbal codes, but also by the perceptual images of multi-level modalities. The ability to take a variety of shapes marks the hypertext as a complex, self-organizing system, containing a huge reservoir of knowledge that a human being can neither learn, nor perceive in full. It is important to note that the emergence of hypertext indicates the formation of non-linear type of thinking arising from new information technology wiping off distance and time limits (LIANG, 2016). This research highlights the features of hypertext connected with its functioning in multilingual discourse, which allows representing the multi-level process of production and reproduction of other languages' senses (RYABOVA, 2007). We have analyzed 500 creolized texts in the media, advertising, and the Internet (2018-2019) in order to identify the manipulative potential of the texts with heterogeneous textures. The basis of our methodology was the determination of the verbal text and illustration content ratio. This article poses that if an illustration is a visual representation of text information, then by using illustrations; one can change verbal text 
content. Such an adjustment is made for a specific purpose. Given that this goal is not directly declared to the mass recipient and that the perception of a creolized text occurs in the conditions of noncritical, we consider that similar texts have manipulative potential (KEATON; GILES, 2016).

To determine the content of the text, we used a formalized analysis of the text semantics, its subject-specific content (NOVIKOV, 1983), after which the critical denotations of the text and image were determined. In this case, not only the plot-object content of the illustration was taken into account, but also the semantics of the form. To identify the semantics of the form, the data from previous studies were used (RIEDEL, 1999; WILDGEN; SEMIOTIK, 2013; SHKURKO; MARDIEVA; SHCHUKLINA; CHUDINOV， 2018; NASYROVA; KHABUTDINOV; KHABUTDINOVA, 2016).

We considered the location of objects in the image, using specific geometric shapes and colors as the main components of the form.

Next, the comparison of the text and illustration formalized content was carried out. Since the content is based on a set of denotations, and the denotations themselves can be defined as concepts, the classification of relations between concepts was taken to determine the relationship between them (VOISHVILLO, 1989; VERBOON; VAN DIJKE, 2012). Based on the analysis, conclusions were drawn about the degree to which the content of a verbal text corresponds to the content of illustrations, and the possible manipulative intentions of creolized text creators were determined.

\section{Results}

Numerous definitions of the concept "text" in the modern linguistics may be explained by a) the formal-structural variability of texts; b) their functional and stylistic diversity; c) the difference in the approaches to the study of the text; d) the absoluteness of its formal-structural aspects, the orientation of the definition of the text into one or several categories. Despite the carefulness of this definition of text, scholars criticize such aspect as "objectified only in a written form", noting that the proposed definition covers only texts in written form. Some linguists make a distinction between the notion "text" viewed as a physical product, a result of communicative events and "discourse" viewed as a dynamic process of expression and interpretation of information. As stated by Bender and Lascarides (2019) "a text is the result of communication, its structural and linguistic component, and, at the same time, its final realization; the structure in which the "living" discourse is embodied after its completion 
(BENDER; LASCARIDES, 2019). In the last decades of the last century, the communicativepragmatic approach to the understanding of text became of particular relevance. The main idea of this approach is to emphasize the communicative function and intention of the text content, as well as to stress that "a text is to serve as a vehicle for a transmission of the author's intended meaning to the reader" (LEEWEN, 1981, p. 48). Thus, a text without communicative function is not a text. Text as a verbal, "classical" form of information is less popular as semiotic heterogeneous complex. In semiotics, the text is understood as any sign, any form of communication, including picture, dance, and road signs. According to the semiotic approach, today's texts are mainly heterogeneous phenomena, the sets of semiotic elements, which have a formal connectivity and meaningful integrity. From the very beginning hypertext has often been regarded as an unlimited information structure, e.g. the concept of "open hypertext". The idea of dynamically extensible hypertext, which is not a ready-made product, but the thing constantly weaving new meanings in its network, was introduced in the humanities by the philosophy of post-modernism. The fundamentals are the principle of deconstruction, the language of the unconscious, schizoanalysis, the concept of the rhizome, the concept of the "open" text. Overall, the humanitarian approach to media hypertext study can be considered in two ways: on one hand, "hypertext as media", in which the communicativeenvironment of virtuality determines the formation of new cultural paradigms and on the other, "polycode hypertext as a special language" - the emergence and functioning of new language systems signs, symbols, "language games" (for example, so-called "Olbanian language", "Ruglish"), etc. A polycode text is characterized by all those properties appropriate of the rest texts; however, they take a new sound with regard to heterogeneous messages. Informational content of a polycode text is identified by the efficiency of its polycode structure, allowing duplicating information many times over. A polycode text is both adaptive and non-adaptive at the same time. The dynamics of polycode text appears through the interpenetration, complementarity and mutual interaction of polycode components, ensuring the dynamism in case of semantic origination. A verbal component is the integral constituent of polycode text. This verbal component narrows the variants of interpretation and perception. It is the specific nature of figurative and verbal signs that influence the process of their perception as points out Aimoldina and Zharkynbekova (2014). A verbal message is linear and may be perceived only in sequence. Perception of a verbal text is directly relevant to semantic and linguistic level of identity, i.e. it is refracted directly through the linguistic world view. Perception of figurative signs is directly oriented towards the conceptual level of linguistic identity, which is usually expressed in comprehensibility of the majority of images by people, speaking different languages. Alongside 
with the general properties for all texts, such as informational content, coherence, composition completeness, divisiveness, emotional breadth and etc., a polycode text is characterized by a number of the specific ones, including: heterogeneity of constituents, poly-informational content, excessiveness, ability of simultaneous uniqueness and a great degree of interpretiveness. The special attention should be given to a poly-informational content, appearing in availability of several information varieties, presented by a literal text, graphics and paragraphemics by means of which the language and technical codes can be expressed (ACHWAN; GANIE-ROCHMAN; ALAMSYAH; TRIANA, 2020). A polycode text is characterized by four distinctive features: operating method, sphere of effect, nature and a number of signs, type of function. On one hand, a polycode text focuses the fact of cooperation of different codes if one understands a code as a system of conventional values, symbols, signs and rules of their combination against each other to transmit, process and store (memorize) information in a form to be the fittest for this purpose. In linguistics such comprehension of a code is applicable for language signs and rules of their combination against each other. In sociolinguistics the notion of a "code" is assigned to socially variable (stratified) language variants, as well as to identify some strategies of verbal planning. And, on the other hand, the term "polycode text" draws attention to a textual nature of an identified phenomenon, its meaningful and semantic integrity that recedes into the background when using the term "communicant". Hence, the usage of the term "polycode text" is reasonable and natural when identifying a text as a coherent whole to be made up of several semiotic codes. A polycode text in its broad meaning may be presented both by a single-channel one, where one channel of perception is involved to read such texts, and multi-channel one, where it is required to involve additional channels of perception to analyze the texts.

The following relationships were found between the content of a verbal text and the content of an illustration on our material.

Incomparability. Quite often, advertising uses the tactics of famous people attraction, when a product is advertised by media characters, portraying ordinary consumers. The effect of such advertising is the desire to imitate famous people. A well-known person is in no way associated with an advertised product. Hence the relation of incomparability arises.

Sometimes, an ambiguity technique is used to create incomparable relationships. In advertising and the media, ambiguous words/homonyms appear not due to objective necessity, but because of their potential. At that, sometimes, the values of the peripheral (or not the most frequent) meanings of words are updated. For example, an advertisement for a shampoo with 
the words "New turn" and the image of a curl (the meaning "turn-curl" is actualized only with a picture).

Equivalence or Crossing. These relations between the components of creolized text exist when repetition tactics are used: the same information is presented in a verbal and visual way. Through intrusive repetition, the authors try to "imprint" the necessary information into the minds of the recipients.

What is the way of text information visualization? Often used tactics of referring to stereotypical representations of various fragments of a picture of the world, for example, family, food, work, handsome person, etc. Visualization of these representations is the easiest way to represent the text (MARDIEVA, 2016).

Another case of equivalence or crossover relationship emergence is the use of disambiguation tactics. If a multi-valued word/homonym was used in the text without a stylistic purpose (for example, puns), then usually such a text does not allow double interpretation. However, an ambiguous word/homonym in the title of such a text can be understood in different ways. An example is the phrase "ancient castles", for which the use of illustrations becomes a necessity.

Crossover relationships arise when they implement pulling out of context tactics. An illustration of the text is nearly pulling out of context. It emphasizes the selected fragment, which may not be interpreted by the recipient precisely as the verbal text suggests. The same is valid for crushing tactics - by which, in the case of illustration, we mean the use of a visual series of several images.

Often there is an intersection of the connotative information of a text modal keys and an image (ANISIMOVA, 2003). These cases can be seen as emotional correction tactics. For example, a well-known advertisement of a charity fund with the words "Will you push me away?" and a photograph of a sad and serious boy. This also includes the design of invitations to various celebrations.

Subordination. Such relationships are often found in a creole text. This, for example, includes all the cases of groups of goods advertising with hyperonyms (fruits, vegetables, shoes, clothes, etc.) and the images of specific fruits, vegetables, etc. Subordination relationships do not occur during a creolized text writing.

The relationships of contradiction or opposition are possible. There were no cases in our material when the verbal text contradicts the image. However, the contrast of modal keys is possible. For example, a conference advertisement: the text "Conference: Internet Breakthrough - Business Development 2.0 - October 1" and the image of the "Vivat" sign. There is the 
opposite of the verbal text business style and the informal style of illustration. The purpose of this combination is obvious - to "cheer up" the verbal text a little.

\section{Discussion}

We suggest that by analyzing the relationship between the content of the verbal text and the content of the illustration, the intentions of the creolized text creator can be revealed.

With the so-called "bonafide" illustration, the author does not attempt to change verbal text content. Its purpose is to visualize textual information as if to "support" a verbal text. Disambiguation tactics and repetition tactics accomplish this.

This also includes the cover tactics of authority. However, this tactic cannot be equated in effect to the previous ones (they are built on the equivalence/crossing relations, and this tactic is built on the relations of incomparability). The manipulation is that an "advertising person" is usually not an expert in what he advertises, and his actual use of the advertised goods is not verified.

Furthermore, of course, the scope of manipulation includes the imposition of images, which inevitably occurs during advertising with the involvement of recognizable faces. For example, a well-known trick in car advertising is the use of beautiful female models. New technological advances are not only "reinforced" by female beauty, but also receive a shade of human beauty, sexuality and so on completely alien to technique. For example, the organizers of the event decided that there would be no model girls at the Shanghai Motor Show. The rejection of female models shows that the organizers are aware of the manipulative potential of such advertising and refuse its transforming component.

A change in a verbal text content can be seen in many cases with the cross-relationship between the content of the text and the content of the illustration, for example, when they use the tactics of pulling out of context and fragmentation. If an illustration does not change the hierarchy of meanings of a verbal text, and also does not have a large interpretative potential, then we can talk about the use of repetition tactics (MUKHAMETZYANOVA; MARDIEVA, 2017). Deviation from these requirements allows us to classify tactics as transforming the text content.

Crushing creates a new text different from the original. The level of difference significance depends on several factors, primarily on what information a verbal text is visualized and what is released. 
In certain cases, it is possible to create a visual series based on a verbal text, upon which the recipient will receive information that is far from the information of the verbal text. However, such creativity requires considerable effort and skill, and such cases cannot be quantitatively significant. Typically, the part of a verbal text content is visualized. The recipient perceives a shortened, schematic content of the verbal text based on these images. Obviously, in any case, the content of the source text undergoes transformation.

Ambiguity tactics are also used to transform a verbal text. The second meaning of ambiguous words or homonyms arises only when the text is combined with the image, which creates ambiguity and a verbal text transformation.

The tactics of referring to stereotypes can be considered in many cases as the transformation of the text content since traditional representations are some simplification and schematization of the real state of things. An example is the analysis of visual metaphors (symbolic images) of happiness (ULANOVSKY, 2019). Ulanovsky, having analyzed the drawings, through which the image of "happiness" is most often visualized, came to the conclusion that they all represent this image inaccurately (and sometimes incorrectly). However, if traditional representations without distortion present information of a verbal text, which can usually be found when they illustrate specific concepts and realities, then the tactics of referring to traditional representations serve to "support" the content of a verbal text. The use of common images in illustration can serve completely different purposes (from recognition improvement to a verbal text content distraction).

Contrast juxtaposition tactics can be used to "support" the content of a verbal text if the verbal text contains this juxtaposition explicitly. Enhancement of "contrast" through illustration can be seen as a transformation, and contrast creation as a departure from the text content.

The tactics of emotional attunement can be used for various purposes. It all depends on the ratio of the illustration information and the verbal text information. If the emotional mood of an illustration corresponds to that described in a verbal text, then there is the text content "support".

If, for example, an image carries a positive/negative emotional attitude during a text illustration with information that does not have an emotional assessment in a verbal text, but which can be evaluated positively/negatively and rationally (for example, a wedding/funeral), then the tactics of illustration are aimed at the verbal text content transformation. The illustration adds an emotional load appropriate to the text content. However, since such a supposed text is written unemotionally, the illustration transforms the verbal text by the very fact of emotionality creation. Such a subset of tactics can be considered as the tactic of 
emotionality and expressiveness escalation. If the illustration emotionality enters into the relationship of contradiction or opposition with the emotional load of a verbal text, then there is some deviation from the text content.

After the data analysis, we can distinguish three groups of manipulative tactics. The first can be called supportive (our term): with their help, the content of the text seems to receive support, additional protection from the illustration. The second group is transforming tactics (our term). Their use leads to the transformation of the text content and its change. The third group is distracting tactics (our term). They are designed to distract an addressee from verbal text content. Using the tactics of the first group, one can "say" the same with the illustration; with the tactics of the second group, you can add something, change the content of a verbal text through the illustration, and using the tactics of the third group one can distract the recipients from verbal text content.

The border between these tactics is very arbitrary. It is proved that the content of an image and the content of a verbal text cannot be the same. Illustration always transforms verbal text content.

1) Transcoding the language of one sign system to the language of another has the motivation for transformation. There are two types of motivation: the need, determined by way of information presentation, or the need to achieve the equivalence of directed impact. The transformation of a verbal text is recognized as necessary, after which visual parameters are given to the verbal text objects, without which an image is impossible.

2) Transformation should be the minimal. That is, the visual criterion should be "invisible" as much as possible so as not to catch the eye and not "impose" its semantics.

If the transformation of a verbal text content during an image adding meets the criteria of minimalist and necessity, then we can state the use of tactics of the first group. If the changes are more than minimal and necessary, then the tactics of the second group are applied.

The border between the second and third groups is quite challenging to determine and actually comes down to the question about the changes which do not change the essence of an object, and about the changes through which an object becomes something else. In these cases, a logical analysis of the full content of creolized text components and verbal text and image individual parameters can be used. The presence between the text and illustration content (or their separate parts) of the relationship of opposition and incomparability should be the 
indicator of an attempt to distract recipients from verbal text content. Revealing a significant number of such relationships means that the author of a creolized text used distraction tactics.

Which number is significant can be determined by mathematical methods. It is necessary to establish the percentage value at which the presence of incomparability, contradiction, and opposition relationship between the content of a verbal text and an illustration can be considered as a focused withdrawing tactic of the text author.

Thus, a polycode text is a text built of the combination of semiotically heterogeneous components of a verbal text in a single graphic space as well as signs of another semiotic nature (SONIN, 2005). The term "polycode" focuses on the interaction of different codes in one semantic space and draws attention to the textual nature of text, its semantic integrity, and textuality. Therefore, we fully support the opinion of Chernjavskaja, who believes that the term "polycode text" is used for denoting a coherent wholeness consisting of several semiotic codes (CHERNJAVSKAJA, 2009). Nowadays the term "polycode text" is actively used by linguists including Selivanova, Sonin, Chernjavskaja. Taking into account the above mentioned studies we fully agree with the opinion of the scientists who note, that the terms "polycode" and "semiotically complicated" texts are the most effective while denoting the heterogeneous messages (texts) created by various sign systems/codes with the same significance of all semiotic systems involved in the formation of this text.

Theoretical provisions allow us to develop a general model for a creolized text study by mathematical methods. However, it must be borne in mind that numerical values should, in no case, be taken as absolute data in such studies. They are only a way to identify specific relationships of information from different carriers and the intentions of text creators. Such a complicated procedure is necessary because manipulation is a hidden effect. By analyzing a creolized text "by eye," one may not notice the manipulative effect of an experienced professional.

A creole text, as can be seen from the characteristics of its perception, is an effective means of a manipulation strategy implementation. Its manipulative potential is enhanced by the fact that the recipients are not critical to a creolized text formal aspect, as it is not in the focus of their attention.

\section{REFERENCES}

ACHWAN, R.; GANIE-ROCHMAN, M.; ALAMSYAH, A. R.; TRIANA, L. University reform and the development of social sciences in Indonesia. International Journal of Educational Development, v. 7, n. 8, p. 102269, 2020. 
AIMOLDINA, A.; ZHARKYNBEKOVA, S. Incorporating authentic models into business letter writing within the ESP course at Kazakhstani universities. Hacettepe University Journal of Education, v. 29, n. 29-2, p. 16-33, 2014.

ANISIMOVA, E. E. Linguistics and intercultural communication (based on creolized texts): Textbook for the students of foreign languages universities. Moscow/ Russia: Publishing Center Academy. (2003).

BENDER, E. M.; LASCARIDES, A. Linguistic fundamentals for natural language processing ii: 100 essentials from semantics and pragmatics. Synthesis Lectures on Human Language Technologies,v. 12, n. 3, p. 1-268, p. 2019.

CHERNJAVSKAJA, V. Linguistics of the text. polycode, intertextuality, interdiscursiveness. Institute of Linguistics RAS, v. 1, n. 2, p. 5-21, 2009.

FARZADNIA, S.; GILES, H. Patient-provider interaction: A communication accommodation theory perspective. International Journal of Society, Culture \& Language, v. 3, n. 2, p. 17$34,2015$.

KEATON, S. A.; GILES, H. Subjective health: The roles of communication, language, aging, stereotypes, and culture. International Journal of Society, Culture \& Language, v. 4, n. 2, p. 1-10, 2016.

LEEWEN, E. Sternes "Journal to Eliza": A semiological and linguistic approach to the text. Tübingen/ Germany: Gunter Narr Verlag, 1981.

LIANG, M. Y. Achieving multimodal cohesion during intercultural conversations. International Journal of Society, Culture \& Language, v. 4, n. 2, p. 55-70, 2016.

MARDIEVA, L. Pre-existing visual images and phenomena: A linguistic approach. SGEM, v. 1, n. 3, p. 765-772, 2016.

MERZLYAKOV, D.; IGNATOVA, E. Understanding creolized text in the system "authorreader" on the example of texts with graphic and realistic images. In: INTERNATIONAL CONFERENCE ON PEDAGOGY, COMMUNICATION AND SOCIOLOGY, 2019, Ningbo. Proceedings [...]. Ningbo, China: ICPCS, 2019.

MOUSAVI, S. A.; FARAHANI, A. A.; ARIZAVI, S. An investigation of the linguistic, paralinguistic and sociocultural effects of input on the perception and translation of gerunds by Persian speakers of English. International Journal of Society, Culture \& Language, v. 2, n. 1, p. 119-130, 2014.

MUKHAMETZYANOVA, L.; MARDIEVA, L. The polyfunctuanality in the names of newspapers and magazines. Revista San Gregorio, v. 20, n. 1, p. 148-153, 2017.

NASYROVA, A.; KHABUTDINOV, A.; KHABUTDINOVA, M. Magazine illustration as epoch investigation source (Aisilu (1959) by BaqiUrmanche as an example). Turkish online journal of design art and communication, v. 2, n. 6, p. 3094-3099, 2016. 
NOVIKOV, A. I. Semantics of the text and its formalization. Moscow/ Russia: Nauka Publisher, 1983.

RIEDEL, I. Colors in religion, society, art and psychotherapy. Stuttgart/ Germany: Kreuz Publisher, 1999.

RYABOVA, M. Foreign language as a factor of personality development: methodology for the development of a socio-philosophical concept, Saransk/ Russia: Mordovia University Publishing Houses, 2007.

SHKURKO, V.; MARDIEVA, L.; SHCHUKLINA, T.; CHUDINOV, A. Poster images in a new linguistic and extralinguistic context. Amazonia Investigation, v. 7, n. 12, p. 320-324, 2018 .

SONIN, A. Understanding polycode texts: the cognitive aspect. Institute of Linguistics RAS, v. 5, n. 2, p. 9-19, 2005.

ULANOVSKY, A. False metaphors of happiness. Institute of Linguistics RAS, v. 13, n. 4, p. 10-19, 2019.

VASHUNINA, I. V.; RYABOVA, M. E.; EGOROVA, L. A. Polycode hypertext in polylingual discourse of intercultural communications. Xlinguae, v. 7, n. 4, p. 25-36, 2018.

VERBOON, P.; VAN DIJKE, M. The effect of perceived deterrence on compliance with authorities: the moderating influence of procedural justice. International Journal of Criminology and Sociology, v. 1, n. 5, p. 151-161, 2012.

VOISHVILLO, E. K. The concept as a form of thinking: logical and epistemological analysis. Moscow/ Russia: Moscow State University, 1989.

WILDGEN, W.; SEMIOTIK, V. The development of the visible: from the cave picture to the modern city. Bielefeld/ Germany: Transcript-Verlag, 2013.

\section{How to reference this article}

GARAEVA, V. J.; VASHUNINA, I. V. Polycode: creolized text as manipulation means. Rev. EntreLínguas, Araraquara, v. 7, n. esp. 1, p. 232-245, fev. 2021. e-ISSN: 2447-3529. DOI: https://doi.org/10.29051/el.v7iEsp1.14892

Submitted: $28 / 10 / 2020$

Required revisions: $19 / 12 / 2020$

Approved: $13 / 01 / 2021$

Published: 28/02/2021 